\title{
DośWIADCZENIE DEPORTACJI: PRZEMOC ORĘŻEM SUWERENNOŚCI
}

\author{
AGNIESZKA RADZIWINOWICZÓWNA
}

\begin{abstract}
Abstrakt: Literatura dotycząca nowoczesnej państwowości wskazuje, iż zarówno deportacje, jak i sama możliwość ich dokonania, czyli deportowalność migrantów, wytwarzają suwerenność w obliczu niezgodnych z prawem międzynarodowych migracji, które postrzegane są jako „utrata kontroli”. W artykule podejmuje się, przy użyciu koncepcji „państwa jako przeżywanego doświadczenia”, próbę dialektycznego połączenia teorii dotyczących państwowej suwerenności z indywidualnym doświadczeniem osób deportowanych. Autorka, bazując na zebranych w Meksyku narracjach byłych deportowanych ze Stanów Zjednoczonych, opisuje, jak kontinuum przemocy doświadczanej przez migrantów w trakcie i po deportacji rekonstruuje amerykańską suwerenność w miejscu pozalegalnej strefy wytworzonej wraz z ich „nielegalnym” przekroczeniem granicy terytorium państwa amerykańskiego. W państwach narodowych przemoc wobec deportowanych odtwarza symboliczną granicę wspólnoty narodowej, natomiast nieobywateli dyscyplinuje, wytwarzając potrzebną suwerenowi rządomyślność. Ma ona transnarodowy charakter, bowiem bolesne doświadczenie deportowanych może ich zniechęcać do powrotu do Stanów Zjednoczonych oraz powstrzymywać niemigrantów przed „,nielegalna” migracja.
\end{abstract}

Słowa kluczowe: przemoc, deportacja, suwerenność, migracje, Meksyk, Stany Zjednoczone Ameryki 
Współczesne granice wznoszone są nie tyle przeciw innym suwerenom, ile przeciw pozapaństwowym transnarodowym aktorom, w tym migrantom (Sassen 2012, 119). Kontrole prowadzone na granicy i w głębi terytorium maja na celu wykrycie i zdyscyplinowanie ludzi, których mobilność kwestionuje państwową suwerenność. Jak zauważają między innymi William Walters (2002) i Nicholas De Genova (2010), zarówno deportacje, jak i ich możliwość, czyli deportowalność (deportability) migrantów, wytwarzają suwerenność nowoczesnego państwa narodowego w obliczu niezgodnych z prawem migracji. Jak staram się wyjaśnić w niniejszym artykule, jeśli przyjmiemy inną optykę, ogniskującą się na jednostce, dostrzeżemy, że suwerenność państwowa opiera się na doświadczanym przez migrująca jednostkę kontinuum przemocy, którego kulminacja - lecz nie końcem - staje się proces deportacji.

Za punkt wyjścia przyjmuję założenia teoretyczne dotyczące tworzącej suwerenność funkcji deportacji, które przedstawiam w kolejnej części artykułu. Jego ambicją jest jednak dialektyczne połączenie teorii dotyczących reżimów deportacyjnych z empirią w celu opisania doświadczenia deportacji. Mając bowiem w pamięci teorie dotyczące poziomu makro (polityki i ekonomii), analizę lokuję na poziome mikro.

Niniejsze rozważania prezentują wyniki moich badań etnograficznych prowadzonych wśród meksykańskich obywateli w przeszłości deportowanych ze Stanów Zjednoczonych Ameryki. Stany Zjednoczone deportują rocznie ponad trzysta tysięcy osób (U.S. Department of Homeland Security 2016, 103), więcej niż wszystkie kraje Unii Europejskiej razem wzięte. Walters (2002) i Deborah Boehm (2011) określają współczesne czasy wiekiem deportacji. W trakcie prezydentury Baracka Obamy deportowano historyczną liczbę ludzi; rekordowy był rok 2013, kiedy „wydalono”1 ze Stanów Zjednoczonych 438,421 osób, wśród których obywatele meksykańscy stanowili 72 procent (Simanski 2014, 5-6). Choć brak jeszcze oficjalnych danych, popierające Demokratów amerykańskie media informowały, że w roku wyborów prezydenckich w Stanach Zjednoczonych skala deportacji spadła (Preston 2016; Breisblatt 2016), co było pojednawczym sygnałem wysłanym przede wszystkim do obywateli o imigranckim pochodzeniu. Kontrastowało to $\mathrm{z}$ wyborczymi obietnicami kandydata Republikanów, zapowiadającego deportacje sans papiers, aby - jak brzmiało hasło wyborcze Donalda Trumpa - „uczynić Amerykę ponownie wielką”. Ten frazes dobitnie pokazuje, że deportacja jest środkiem renegocjacji suwerenności. Prezydentura Trumpa przyniesie zapewne wzrost skali deportacji z amerykańskiego terytorium.

\footnotetext{
1 Oficjalna nazwa procedury deportacji, removal, które tłumaczę jako „wydalenie”, dosłownie znaczy „usunięcie”. Medyczny charakter tego określenia wskazuje na biopolityczny charakter deportacji.
} 


\section{Przemoc budująca suwerenność}

Źródłem inspiracji wspomnianych powyżej De Genova'y i Waltersa jest filozofia Giorgio Agambena (2008). Zdaniem filozofa, suwerenność jest wytwarzana za sprawą wykluczania ludzi niebędących członkami wspólnoty politycznej. Deportacja jako forma przymusowego opuszczenia państwowego terytorium przez „cudzoziemców” pojawia się dopiero po powstaniu państw narodowych (Walters 2002). Znana z historii forma wykluczenia, jaką było wygnanie, rzadko kiedy ich dotyczyła; przypadek Żydów i muzułmanów wypędzonych z Hiszpanii w 1492 roku był jednym z nielicznych wyjątków Kedar 1996, 47). W przeszłości skazywano głównie na wygnanie z miast i sankcja ta dotyczyła ubogich czy przestępców, postrzeganych jako obciażenie dla obywateli miasta. W państwach narodowych deportacja odgrywa natomiast doniosłą rolę w tworzeniu narodu jako wspólnoty wyobrażonej (Soysüren et al. 2016). W książce pt. „Deportation Nation” Daniel Kastroom (2007) argumentuje na przykład, że na przełomie wieków dziewiętnastego i dwudziestego deportacja milionów imigrantów przybywających z Europy do Stanów Zjednoczonych była ważnym elementem tworzącym tożsamość narodu amerykańskiego - podkreślała bowiem symboliczną granicę pomiędzy „my” i „oni”. Również dziś amerykański reżim deportacyjny nakierowany jest na grupy etniczne, a władze imigracyjne oskarżane są o profilowanie rasowe osób zatrzymywanych do kontroli. Pytanie, jakie ma być amerykańskie państwo narodowe kształtowane przez rasistowski reżim deportacyjny pozostaje zatem aktualne również współcześnie.

Deportacja to technologia obywatelstwa (De Genova 2010), która wytwarza „cudzoziemców” i wyklucza ich, czy to przez permanentne wyłączenie z formalnych uprawnień, które - przynajmniej teoretycznie - niesie obywatelstwo (Coutin 2000), czy przez deportację. Jak wskazują De Genova i Nathalie Peutz (2010, 14), „deportacja kilku [osób, przyp. AR] wraz z trwałą codzienną deportowalnością niekończących się innych" to koszt, który trzeba ponieść, aby odbudowywać suwerenność w czasach globalizacji. De Genova (2004) wskazuje na performatywny aspekt tego, co nazywa „spektaklem na granicy” - migawki zmilitaryzowanych kontroli granicznych czy przemocy użytej wobec migrantów, którzy znajduja się na terytorium państwa narodowego również mają narodotwórczy charakter i tworzą „obcych”. Ich deportacja umacnia państwową suwerenność na poziomie wykluczającej zbiorowości, ale - jak będę starała się udowodnić na podstawie zebranych danych - suwerenność ta umacnia się także w odczuciu jednostki deportowanej (Radziwinowiczówna 2016).

W literaturze deportację wiąże się z przemoca; na przykład Peutz i De Genova (2010) argumentują, iż ogranicza ona ludzką swobodę przemieszczania się, a ta według Hannah Arendt $(1968,9)$ jest warunkiem wstępnym każdego innego rodzaju wolności. Areszt imigracyjny poprzedzający deportację stoi w sprzeczności z międzynarodowymi umowami, 
takimi jak Powszechna Deklaracja Praw Człowieka (United Nations 1948, Art. 9) i Amerykańska Konwencja Praw Człowieka (Organization of American States 1969, Art. 7), które chronią ludzi przed nieuzasadnionym pozbawieniem wolności. W literaturze dotyczącej deportacji często jednak implicite zakłada się związek między suwerennością a przemocą. Weberowska definicja władzy $(2002,39)$ wskazuje na możliwość przeprowadzenia swej woli nawet wbrew oporowi. W przypadku władzy suwerennej możemy zatem mówić o „prawomocnej” z punku widzenia państwa przemocy - tej, która użyta zostaje w imię suwerenności, czyli „samostanowionego i absolutnego prawa narodu do ustalania własnych granic; prawa, o którym sądzi się, że wpisane jest w samą istotę państwa narodowego" (Ngai 2004, 11). Niezależnie od typu przemocy, z jakim mamy do czynienia (por. następna część niniejszego artykułu), zaprowadza ona porządek suwerennego państwa narodowego w miejscu pozalegalnej, sprzecznej z nim cienistej strefy „nielegalności” wytwarzanej przez migrantów. Przemoc fizyczna brutalnie wyrywa ich z tej strefy, symboliczna natomiast rekonstruuje w niej prawo, które ponownie wyklucza ich z obszaru legalności jako „deportowalnych cudzoziemców” (,removable aliens”).

Celem niniejszego artykułu jest podyktowana chęcia połączenia rozważań dotyczących państwowości z doświadczeniem jednostki próba odpowiedzi na pytanie, jak za sprawą przemocy państwowa suwerenność lokowana jest $\mathrm{w}$ indywidualnym doświadczeniu. Sięgam po osadzoną w nurcie fenomenologii koncepcję „państwa jako żywego doświadczenia”. Jennifer Correa (2013, 100) definiuje ja jako „realizowane przez aparat bezpieczeństwa miejscowe akty władzy, które kształtują [...] emocje, działania i światy społeczne podmiotu”. „Państwo jako żywe doświadczenie” bada światy przeżywane działających podmiotów i dąży do zrozumienia, jak ich elementem stają się działania aparatu państwowego.

\section{Konceptualizacja typów przemocy}

W kolejnych częściach artykułu przyjrzę się, z jakimi rodzajami przemocy wiąże się deportacja, niezbędne jest zatem wstępne ich zdefiniowanie. W antropologii przemocy (Scheper-Hughes i Bourgois 2004) zakłada się bowiem, że nie ogranicza się ona do zadawania fizycznego cierpienia. Slavoj Žižek proponuje, by mówić o przemocy subiektywnej i obiektywnej (2010). W przypadku tej pierwszej możliwe jest zidentyfikowanie sprawcy - podmiotu zadającego przemoc; nie jest to jednak proste w przypadku przemocy obiektywnej. Do tej ostatniej zalicza Žižek przemoc symboliczną i systemowa. Według autora tej pierwszej koncepcji przemocy, Pierre'a Bourdieu, jest ona sprawowana przy udziale ofiary, w miarę jak akceptuje ona własne podporządkowanie. Zdaniem Bourdieu przemoc symboliczna jest najsilniejszą, bo niekwestionowana, formą dominacji (Bourdieu i Wacquant 2001). U Žižka definicja przemocy systemowej odpowiada temu, co za Johanem Galtungiem (1969) zwykło się określać przemoca 
strukturalną. Opiera się ona na wzajemnym wpływie statusu społecznego i podatności na fizyczne i emocjonalne cierpienie. Philippe Bourgois $(2001,7)$ pisze, że przemoc strukturalna to:

polityczno-ekonomiczna organizacja społeczeństwa, która narzuca warunki fizycznego i emocjonalnego cierpienia, począwszy od wysokich wskaźników zachorowalności i umieralności, po ubóstwo i niebezpieczne warunki pracy. Na poziomie makro jest ona zakorzeniona $\mathrm{w}$ strukturach takich jak nierówne warunki handlu międzynarodowego, a lokalnie przejawia się w opierających się na wyzysku rynkach pracy, układach handlowych i monopolizacji usług.

Bourgois (2001) proponuje, by analiza sytuacji danego aktora uwzględniała nie tylko przemoc subiektywną, lecz również jej obiektywne formy. Podleganie kilku typom przemocy nazywa ten autor „kontinuum przemocy”.

Tradycyjnie w antropologii przemocy wyróżnia się troje aktorów: ofiarę, sprawcę i świadka, który klasyfikuje dane działanie jako przemoc (Riches 1986, 9). Badania dowodza jednak trudności w jasnym odróżnieniu ofiary i sprawcy (Ramírez Valenzuela 2012), ponieważ w różnych kontekstach społecznych jedna osoba może wchodzić w różne role oraz być postrzegana jako w nich występująca. Jasne pozostaje jednak, iż oprawca zadaje krzywdę, ofiara ją cierpi, a świadek obserwuje działanie, jest w stanie je opisać (dać świadectwo) i klasyfikuje je jako akt przemocy. Z tej perspektywy niemożliwe jest badanie przemocy bez świadka, ponieważ - jak ujęli to Nancy Scheper-Hughes i Bourgois (2004, 2) - „przemoc jest w oku obserwatora”.

Badanie doświadczenia przemocy bazujące na narracjach zamiast naocznej obserwacji stanowi wyzwanie dla wspomnianego powyżej trójkąta przemocy. Nie byłam świadkiem deportacji podmiotów badania; niemniej w analizie oraz podczas pracy nad tekstem klasyfikuję działanie, o którym mi opowiedziano, jako „akt przemocy”. Możemy mówić o „podwójnym świadku” - podmiot, który potencjalnie był ofiarą (lub świadkiem czy sprawca) przemocy, i ja - badaczka, która analizuję jego wypowiedzi i klasyfikuję jego doświadczenie jako „przemoc”. Proponuję tego pierwszego określić mianem świadka „pierwszego rzędu”, natomiast badaczkę - świadkiem „drugiego rzędu”, nawiązując do rozróżnienia zaproponowanego przez Alfreda Schütza w fenomenologii $(1953,3 ; 1962,6)$. Schütz wyróżnił konstrukty pierwszego i drugiego rzędu: te pierwsze to pojęcia, którymi operują badani i za pomocą których tłumaczą sobie przeżywane światy. Konstrukty drugiego rzędu to kategorie o bardziej ogólnym i naukowym charakterze, opisujące szeregi szczegółowych i potocznych konstruktów pierwszego rzędu.

\section{Etnografia deportacji}

Uznając doniosłe znaczenie teoretycznych rozważań dotyczących deportacji, Nathalie Peutz (2010) apeluje o prowadzenie etnografii deportacji. Polega ona na dążeniu do zrozumienia 
żywego doświadczenia deportacji i jej konsekwencji poprzez etnografię prowadzoną wśród deportowanych osób. Badania, które posłużyły za podstawę niniejszych rozważań zrealizowałam w Meksyku w San Ángel, miejscowości o wiejskim charakterze - lub używając hiszpańskiego terminu - w pueblo. San Ángel (nazwa fikcyjna, podobnie jak wszystkie imiona rozmówców) położone jest w stanie Oaxaca, w peryferyjnym i ubogim regionie Dolna Mixteca.

Podobnie jak w wielu innych meksykańskich miejscowościach, migracje w San Ángel sa sposobem walki z ubóstwem. Mobilność międzynarodowa zaczęła się w pueblo w latach pięćdziesiątych dwudziestego wieku, kiedy około stu mężczyzn wzięło udział w programie rekrutacji meksykańskiej siły roboczej do Stanów Zjednoczonych. Prowadzony w latach 19421964 program „Braceros” miał za zadanie wypełnienie meksykańskimi migrantami niszy pozostawionej na amerykańskim rynku pracy przez mężczyzn walczących na wojennych frontach. Po jego zakończeniu amerykańskie wizy stały się praktycznie niedostępne dla niewykwalifikowanych rolników z meksykańskich peryferii, i chłopi z San Ángel zaniechali wyjazdów do Stanów Zjednoczonych na rzecz migracji wewnętrznych. Jednak w późnych latach siedemdziesiątych ponownie zaczęli przekraczać amerykańską granicę i z czasem, w latach osiemdziesiątych i dziewięćdziesiątych, kiedy Meksyk przechodził kryzysy finansowe, migracje te znacząco przybrały na sile. Mimo braku stosownych dokumentów migranci dostawali się do Stanów Zjednoczonych przez zielona granicę, co w pueblo określa się mianem „migración por el monte” - migracja przez góry. W literaturze wskazuje się, że po zakończeniu programu „Braceros” amerykańskie władze nieoficjalnie importowały meksykańską siłę robocza przez zielona granice (Cockcroft 1986; Kearney 2004; Massey et al. 2003), wychodząc naprzeciw oczekiwaniom pracodawców. Wytwarzając deportowalne podmioty, państwo narodowe zapewniało rodzimemu biznesowi podaż podatnych na eksploatację pracowników (Castro Neira 2014, 36-37). Migranci z San Ángel - począwszy od momentu, w którym przekraczali amerykańską zieloną granicę - funkcjonowali w Stanach Zjednoczonych „w cieniu” (Chavez 2012), lub w cienistej strefie „nielegalności”, unikając kontaktów z władzami, które naraziłyby ich na deportację. Z uwagi na niedostępność wiz dla bezrolnych chłopów pochodzących z meksykańskich peryferii, migracja przez góry stała się ważnym elementem kultury migracyjnej (Kandell, Massey, 2002), a umiejętność jej organizowania, zatrudnienia kojota oraz współfinansowanie przez migrantów stały się ważnym elementem migracyjnego kapitału społecznego.

Doświadczenie amerykańskiego państwa przez osoby funkcjonujące w cienistej strefie „nielegalności” było zróżnicowane. Państwo to nie miało dla nich homogenicznego charakteru - świadomi byli różnic istniejących między stanami, zwłaszcza w dziedzinie regulacji i praktyk składających się na lokalne odcienie reżimu deportacyjnego. Deportowani z San Ángel byli świadomi, że stany, w których zamieszkiwali (Kalifornia, Oregon, Waszyngton, New Jersey, Nowy Jork, Nevada, Nebraska i Ohio), miały relatywnie liberalna politykę wobec sans papiers. 
Tłumaczyli to głównie faktem, iż - na przykład w przeciwieństwie do Arizony czy Teksasu nie stanowiły one tradycyjnych kierunków meksykańskiej migracji (z wyjątkiem Kalifornii i Nevady), przeważało w nich poparcie dla Partii Demokratycznej (z wyjątkiem Nebraski i Ohio) i nieprzychylne wobec migrantów nastroje społeczne były słabsze. Moi rozmówcy podkreślali na przykład, że w miejscu, w którym zamieszkiwali, policja migracyjna nie organizowała „łapanek” w zakładach pracy. Migranci z San Ángel często wykazywali się podmiotowym sprawstwem w wyborze miejsca zamieszkania i nie akceptowali biernie przemocy strukturalnej wynikającej z ich statusu migracyjnego. Porównując jakość życia oraz możliwości dostępne migrantom, moi rozmówcy podejmowali decyzje dotyczące mobilności w USA. Podkreślali oni na przykład atrakcyjność stanu Waszyngton, gdzie prawo jazdy było wydawane bez sprawdzania statusu pobytowego kandydata na kierowcę. Dostęp do prawa jazdy - zwłaszcza w miejscach o słabiej rozwiniętej komunikacji zbiorowej - był kluczowy dla podejmowania aktywności ekonomicznej.

Oprócz regionalnego zróżnicowania doświadczenia państwa amerykańskiego, istotne jest uwzględnienie perspektywy czasowej. Przed zaostrzeniem amerykańskiej polityki dotyczącej imigrantów, o której więcej w następnym akapicie, osoby deportowane doświadczały państwa amerykańskiego jako względnie łagodnego. Przed zaostrzeniem kontroli na amerykańskiej granicy i upowszechnieniem polityki „prewencji przez odstraszanie”2 (Prevention Through Deterrence) (De León 2015), deportowani Meksykanie szybko przekraczali ją ponownie, często nie korzystając nawet z możliwości odwiedzenia rodziny w Meksyku. O ile deportacja nie była konsekwencją „łapanki” w ich miejscu pracy, ich pracodawcy często nie dowiadywali się nawet o deportacji pracownika.

Wzrost sekurytyzacji w Stanach Zjednoczonych po 11 września 2001 roku oraz późniejszy kryzys ekonomiczny przyniosły zaostrzenie kontroli i stopniowe zatrzymanie nieoficjalnego programu rekrutacji meksykańskiej siły roboczej. Po 2001 roku znacząco wzrosły nakłady na ochronę południowej granicy; w 2003 roku zatrudniano pięciokrotnie więcej strażników granicznych niż dekadę wcześniej (U.S. Customs and Border Protection, 2014: 3). W San Ángel zaostrzenie kontroli migracyjnych zaowocowało utrudnieniami w przekraczaniu granicy przez góry oraz deportacją części migrantów.

Aby lepiej zrozumieć indywidualne doświadczenie deportacji, dotarłam w San Ángel do dwudziestu siedmiu byłych deportowanych, z którymi przeprowadziłam w języku hiszpańskim wywiady jakościowe. Ich scenariusz - oprócz przyczyn i przebiegu deportacji - dotyczył historii życia rozmówców - zarówno przed, jak i po deportacji. Często jedno spotkanie nie pozwalało

\footnotetext{
2 Rozwijana od 1994 roku polityka prewencji przez odstraszanie polega na zaostrzeniu kontroli granicznej w miastach, w wyniku czego potencjalni migranci wybierają niestrzeżone odcinki granicy na pustyni, które są zarazem najbardziej niebezpieczne. Polityka ta nie tylko bardzo utrudniła przekroczenie granicy „przez góry”, ale i uczyniła nielegalną migrację niebezpieczną dla zdrowia i życia.
} 
na wyczerpanie interesującej tematyki i konieczne były więcej niż jedna wizyta w domu rozmówcy. Ponadto, wywiady z byłymi deportowanymi miały charakter panelowy - oprócz wywiadu w 2012 roku po raz drugi rozmawiałam z nimi na przełomie 2013 i 2014 roku (około półtora roku - dwa lata po pierwszym wywiadzie). W drugiej fali badania wzięło udział siedemnaście osób. Zastosowany wówczas scenariusz badania zaprojektowałam indywidualnie dla każdej z nich - oprócz uzupełnienia materiału, chciałam dowiedzieć się, co zmieniło się w życiu rozmówców od 2012 roku. W sumie przeprowadziłam pięćdziesiąt jeden wywiadów z byłymi deportowanymi, wśród których było dwudziestu trzech mężczyzn i cztery kobiety. Proporcja ta odzwierciedla stosunek kobiet i mężczyzn wśród całej populacji osób deportowanych - według dostępnych danych 87 procent deportowanych Meksykanów to mężczyźni (Velasco i Coubés 2013, 5-6). Meksykanki migrują rzadziej niż Meksykanie, ponadto migrantki rzadziej popełniają wykroczenia, mają rzadszy kontakt z amerykańskimi władzami, a zarazem są mniej zagrożone deportacją. Podobnie jak ogół deportowanych, moi rozmówcy zamieszkiwali w USA wiele lat, niektórzy większość życia. Jeśli wykluczyć z przebadanej grupy osoby zatrzymane podczas próby przekroczenia granicy, pozostałe dwadzieścia jeden osób mieszkało w USA od sześciu do dwudziestu pięciu lat. Co się tyczy analiz, transkrypcje (sporządzone również po hiszpańsku) poddałam analizie przy użyciu programu Atlas.ti.

\section{Przemoc jako żywe doświadczenie państwa}

Analiza narracji dotyczących deportacji wskazuje, że dla jednostki składa się ona z kilku faz lub etapów: zatrzymania i złapania przez amerykańskie władze, sądu imigracyjnego, zatrzymania i przewiezienia do Meksyku. Konfiguracja faz składających się na indywidualne doświadczenie deportacji zależy od jej prawnej procedury oraz sytuacji zatrzymania. Na przykład osoby, które nie są aresztowane lub opuszczaja areszt za kaucją i wnoszą apelację przeciw nakazowi „wydalenia”, nie przebywają w areszcie w trakcie procesu imigracyjnego. Dwudziestu dwóch deportowanych z dwudziestu siedmiu z uczestników mojego badania przeszło przez proces deportacji, na który złożyło się zatrzymanie, areszt i przewiezienie w formie konwoju. To tak zwana deportacja „3D”, od angielskiego detection, detention, deportation.

O ile migranci i deportowani z San Ángel dostrzegali międzystanowe różnice dotyczące cudzoziemców, moje analizy nie wykazały znaczących różnic w doświadczeniu deportującego państwa. Wyjątek stanowi Arizona, której szczególnie surowych antyimigracyjnych regulacji i praktyk doświadczyli rozmówcy zatrzymani tam w trakcie przekraczania amerykańskiej granicy. Niezależnie od stanu, deportacja żadnego z moich rozmówców nie była poprzedzona jakakkolwiek forma zbiorowego oporu obywateli i żaden z nich nie skorzystał z prawa azylu w lokalnych świątyniach, o którym wiele pisze się w amerykańskich mediach. Jak wynika z ich 
narracji, wraz z zatrzymaniem przez amerykańskie władze po prostu nagle „zniknęli” ze swoich rodzin, miejsc pracy, kręgów społecznych czy sąsiedztw.

Istnieją dwie przyczyny deportacji: brak dokumentów uprawniających do wjazdu i pobytu na terytorium Stanów Zjednoczonych oraz - w przypadku migrantów posiadających dokumenty pobytowe - skazanie za czyn określany w świetle prawa migracyjnego jako „groźne przestępstwo" (aggravated felony). Ustawa o Imigracji i Obywatelstwie definiuje jako „groźne przestępstwo" szeroki wachlarz czynów - w tym takie, które amerykańskie prawo kryminalne klasyfikuje jako wykroczenia. Osoba skazana na minimum roczne pozbawienie wolności jest uznawana za groźnego przestępcę i po odbyciu kary może zostać deportowana (Inda i Dowling 2013, 15). Mark Dow $(2004,15)$ wymienia listę przestępstw, które mogą skutkować deportacja migrantów posiadających dokumenty pobytowe: „posiadanie narkotyków, przeskoczenie przez bramkę w metrze bez uiszczenia opłaty za przejazd lub nawet pociąnięcie kogoś za włosy”. W rezultacie właściwie każdy nieobywatel może zostać deportowany z terytorium Stanów Zjednoczonych.

Doświadczenie deportacji obfituje w przemoc różnego typu. Zatrzymanie przez amerykańskie władze (czy to na granicy, czy w głębi amerykańskiego terytorium) może łączyć się z przemocą fizyczną. Omówię to na podstawie doświadczenia dwóch osób zatrzymanych przez US Border Patrol (US BP) podczas przekraczania zielonej granicy. Migranci korzystaja w tym celu z usług płatnych przewodników zwanych kojotami. To kosztowne i ryzykowne często ich wędrówki trwają wiele dni, narażeni są na przemoc ze strony przestępców korzystających z bezbronności migrantów, innych migrantów oraz kojotów, jak i naturalne zagrożenia: odwodnienie, udar słoneczny, drapieżne zwierzęta (De León 2015). Dla osób, które nie mają dostępu do amerykańskich wiz, możliwe jest jedynie przekroczenie granicy w cienistej strefie „nielegalności”. Jeśli uda im się dotrzeć do Stanów Zjednoczonych - ich życie również przebiega w cienistej strefie „nielegalności”, którą wytwarzają w odpowiedzi na własną deportowalność, aby pozostać „niewidzialnymi” dla amerykańskich władz.

Jeden z moich rozmówców, Augustín, nie miał szczęścia w przekraczaniu amerykańskiej zielonej granicy. Miał szesnaście lat, kiedy w 2009 roku wspólnie z matką podją próbę. Planowali dołączyć do ojca Augustína w Nowym Jorku, z którym nie widzieli się od jego ostatniego wyjazdu z Meksyku, trzy lata wcześniej. Przekroczenie granicy okazało się jednak bardzo trudne - US BP łapała ich, ilekroć wspinali się na płot dzielący Meksyk i Stany Zjednoczone. Po trzech tygodniach udało im się wreszcie przekroczyć granicę i dotrzeć do autostrady, gdzie na ich grupę czekał samochód. Byli w drodze do Phoenix, gdy US BP zatrzymała ich samochód. 
Augustín: Patrol jechał za nami. Kazali nam wysiąść z samochodu. Miałem w torbie komórkę. Ludzie z La Migración [hiszp. „migracja”, określenie używane w pueblo na amerykańskie służby imigracyjne i graniczne] myśleli, że ja byłem przewodnikiem. Pobili mnie. Skuli mnie, rzucili mnie na ziemię i skopali mnie.

AR: Mocno cię pobili?

Augustín: Nie mocno. No ale tak, nos mi krwawił. I to był ostatni raz, kiedy próbowałem [przekroczyć granicę].

Jennifer, która podjęła próbę przekroczenia amerykańskiej granicy w wieku dziewiętnastu lat, nie padła ofiara przemocy, ale była jej świadkiem. Jej grupa została zatrzymana przez amerykańskich strażników granicznych podczas wędrówki przez pustynne wzgórza dzielące meksykański stan Sonora i Arizonę. Ich kojot umknął strażnikom, podobnie jak wielu innych migrantów, jedynie Jennifer i dwie Brazylijki, które były na czele grupy zaskoczonej przez strażników granicznych, stały w miejscu, przerażone. Towarzyszyli im dwaj Brazylijczycy, którzy nie chcieli zostawić samych kobiet, z którymi zaprzyjaźnili się w drodze.

Jennifer: [Strażnicy] rzucili się na jednego z chłopaków, zwalili go na ziemię i zaczęli go bić. Przyłożyli mu pistolet do ciała. Byliśmy przestraszeni i nie wiedzieliśmy, co zrobić. Dziewczyna z Brazylii powiedziała im: „Dlaczego go bijecie, jeśli wam nic nie zrobił?” [Strażnik] się zezłościł, wstał i przyłożył jej pistolet do czoła. Byliśmy przestraszeni.

Przemoc użyta przez amerykańskich strażników granicznych jest odpowiedzią na cienistą strefę „nielegalności”. Użycie przemocy przez amerykańskie organy władzy (US BP i policję migracyjna, US Immigration and Customs Enforcement, US ICE) konstytuuje w tej pozalegalnej strefie amerykańską władzę suwerenną.

Po obu stronach granicy media donosza o przypadkach użycia przez amerykańskich strażników granicznych przemocy fizycznej wobec osób przekraczających granicę, w tym nieletnich (por. Chavez 2012, 67). Pozostały one jednak niezbadane do 2013 roku, kiedy funkcjonariusze US BP zastrzelili Meksykanina podczas próby przedostania się na amerykańskie terytorium. Wtedy to grupa amerykańskich kongresmenów zażądała kontroli w nadzorującym Straż Graniczną Departamencie Bezpieczeństwa Wewnętrznego (Ortega 2013). W sporządzonym raporcie napisano, że między 2010 a 2012 rokiem dwadzieścia osób poniosło śmierć w wyniku działań US BP. Ponadto ustalono, że 63 procent zażaleń zgłoszonych przez osoby zatrzymane przez Straż dotyczyło możliwego „nadużycia siły”. Jako „,nadużycie siły” zostały zaklasyfikowane takie działania jak „,przemoc fizyczna (zadawanie ran, kopanie, popychanie) [...] i użycie paralizatora, pałki lub gazu pieprzowego” (U.S. Department 
of Homeland Security: Office of Inspector General 2013, 6-7). Tymczasem profilowanie etniczne i „nieprawidłowe zatrzymanie” nie były uwzględnione jako nadużycie siły. Nie wiadomo, jak wiele osób nie wniosło skargi. Augustín i Jennifer tego nie zrobili. Moi rozmówcy naturalizuja przemoc, której ofiara padaja, co jest konsekwencja przekonania, że jest ona ryzykiem wpisanym w tak zwaną, „nielegalną” migrację.

Przemoc doświadczana na amerykańskiej granicy jest pośrednią konsekwencja niedostępności dla meksykańskich pracowników amerykańskich wiz zarezerwowanych dla „wysoce wykwalifikowanych” obcokrajowców. Na legalnej drodze wjazdu do Stanów Zjednoczonych stają ubóstwo i brak wykształcenia - korelaty marginalizacji regionu, z którego pochodzą moi rozmówcy. Innymi słowy, położenie migrantów w strukturze społecznej wystawia ich na zagrożenia, takie jak przemoc ze strony amerykańskich strażników granicznych, ale i oficerów US ICE. Przemoc strukturalna warunkuje ich status migracyjny, przyczynia się do ich narażenia na deportację oraz naraża na inne formy przemocy, zarówno subiektywnej jak i obiektywnej.

Inny rodzaj obiektywnej przemocy, który składa się na doświadczenie osób deportowanych, to przemoc symboliczna. Chociaż jest ona odgórnie narzucona, meksykańscy sans papiers internalizuja identyfikację „nielegalni imigranci” (Gil Martínez de Escobar 2006, 176). Na przykład Amada powiedziała mi: „Nie przekroczyliśmy granicy jako legalni (legales), ponieważ nie mamy dokumentów, bo jesteśmy nielegalni (ilegales)”. Rzekoma „nielegalność” internalizowana jest jeszcze przed emigracja z pueblo i ma duże znaczenie dla subiektywnego doświadczenia sądu imigracyjnego. Wielu podsądnych rezygnuje z wniesienia apelacji przeciw nakazowi deportacji, konstatując, że jako „nielegalni” nie mają innego wyjścia. Zapytałam na przykład Toribia o przyczynę jego rezygnacji z wniesienia apelacji. Odpowiedział: „Ktoś jak ja: Hispanic, karany... Nie... Jak można ich pokonać? To bardzo skomplikowane, więc poprosiłem o dobrowolny powrót.” Przemoc symboliczna działa na najbardziej „osobistym” poziomie (Bourgois 2001:8), a przyswojenie niektórych identyfikacji (takich jak „Hispanic”, „nielegalny”) wraz z towarzyszącym im zespołem wyobrażeń i działań stanowi konsekwencję przemocy symbolicznej, na którą są oni wystawieni w Stanach Zjednoczonych.

Związane z amerykańskim reżimem deportacyjnym kategorie ulegają transnacjonalizacji - po deportacji wielu z moich rozmówców doświadczyło w San Ángel stygmatyzacji jako deportados, „deportowani” - ci, którym się nie powiodło, z których część zaangażowała się w działalność przestępczą - taki bowiem transnarodowy stereotyp dominuje w pueblo. Stereotyp ten aktywuje się zwłaszcza wtedy, gdy deportowany ma „ucieleśnione” emblematy przynależności do gangu, takie jak tatuaże, jest ogolony, nosi luźne ubrania (Radziwinowiczówna 2014). Przemoc symboliczna bazuje na doksycznej akceptacji świata i jak wyraził to Bourdieu - ,ze wszystkich form podskórnej perswazji najbardziej nieubłagana jest ta, która dokonuje się po prostu przez porządek rzeczy” (Bourdieu i Wacquant 2001, 168). 
Przemoc symboliczna ma performatywny efekt - zaszczepia w ludziach identyfikacje i typowe dla nich działania. Žižek (2010, 74) opisał go na przykładzie Afroamerykanów: „»bycie« czarnych (tak jak białych i wszystkich innych) ma charakter społeczno-symboliczny. Gdy biali traktują czarnych jak podludzi, czynią ich w ten sposób gorszymi od siebie na płaszczyźnie tożsamości społeczno-symbolicznej”.

W trakcie procesu deportacji przemoc symboliczna działa poprzez kryminalizacje narzucając deportowanym osobom identyfikacje „przestępca”/„kryminalista”. Wielu moich rozmówców interpretowało fazy deportacji jako kryminalizujące (Sergio: „Myślę, że nie traktują tak nawet przestępców. Kogo pobiliśmy czy zamordowaliśmy, że nas tak traktują?”). Kryminalizacja deportowanych rozpoczyna się już w chwili zatrzymania przez amerykańskie władze:

Jennifer: Potraktowali nas jak przestępców. Zabrali nam sznurówki z butów, związali nam ręce i związali nam stopy. Zarejestrowali nas. Jedna z dziewczyn powiedziała: „To prawie jakby nas rozebrali”, powiedziała. I byliśmy tam. Siedzieliśmy w pełnym słońcu, a oni [strażnicy graniczni] siedzieli w cieniu, obserwując nas. Potem nas dźwignęli i podnieśli. Zabrali nas do wozu. Już prawie nam się udało [przedostać do USA] - obok wozu La Migración były domy. Domy Stanów Zjednoczonych. Autostrada Stanów Zjednoczonych była obok wąwozu [w którym czekaliśmy].

AR: Jakie były domy? Co myślisz o tym, co zobaczyłaś po drugiej stronie [granicy]?

Jennifer: Było ładnie. Ładnie. Były drewniane, inne. Widzisz tam innych ludzi. To znaczy, źle się czuliśmy, bo kiedy zabierali nas [do wozu], w wąwozie byli ludzie. Wybrali się chyba na wycieczkę. Byli tam razem z rodzina. Oni [strażnicy] poprowadzili nas tamtędy. Źle się czułam, bo potraktowali nas jak przestępców. Jeden szedł z przodu z pistoletem, a drugi z tyłu, z pistoletem.

Jennifer zatrzymano w Arizonie, stanie o najbardziej surowej polityce wobec imigrantów (Sadowski-Smith i Li 2016), zwłaszcza po wprowadzeniu programu Operacja Streamline i uchwaleniu prawa stanowego 1070. Operacje Streamline zainicjowano w Teksasie w 2005 roku, ale niedługo później wprowadziły ją też inne przygraniczne stany. Zaowocowała wprowadzeniem surowych kar dla osób zatrzymanych na przekraczaniu granicy; na przykład osoby oskarżone o ponowne niezgodne z prawem przekroczenie granicy często odbywają karę w więzieniach federalnych (Inda i Dowling 2013, 10). Operacja Streamline pozwala także na sądzenie zatrzymanych migrantów w procesach zbiorowych. Po zatrzymaniu Jennifer była sądzona razem z czterdziestoma innymi osobami. Razem z nakazem „wydalenia” otrzymała zakaz wjazdu do Stanów Zjednoczonych na okres dwudziestu lat. W 2010, rok po deportacji Jennifer, wprowadzono w Arizonie inne antyimigranckie rozwiązanie - ustawę senatu 
stanowego nr 1070, nakazująca imigrantom nosić przy sobie dokumenty pobytowe oraz klasyfikująca jako przestępstwo ubieganie się o i podejmowanie pracy przez imigrantów nieuprawnionych do tego (Pope i Garrett 2013, 182-183). Ponadto, ustawa klasyfikuje jako przestępstwo udzielanie pomocy migrantom (Sáenz et al. 2013). Surowe rozwiązania wprowadzone w życie w Arizonie miały za zadanie internalizację dyscypliny przez migrantów i ich „samodeportację" - wyjazd z braku możliwości podejmowania pracy i ze strachu przed deportacja (Castro Neira 2014, 45). To przykład nastawionej na zbywateli regulacji, która wytwarza rządomyślność (Foucault 1991).

Również areszt i przewiezienie do Meksyku kryminalizuja deportowanych. Kryminalizujący charakter maja przede wszystkim biometryczne procedury:

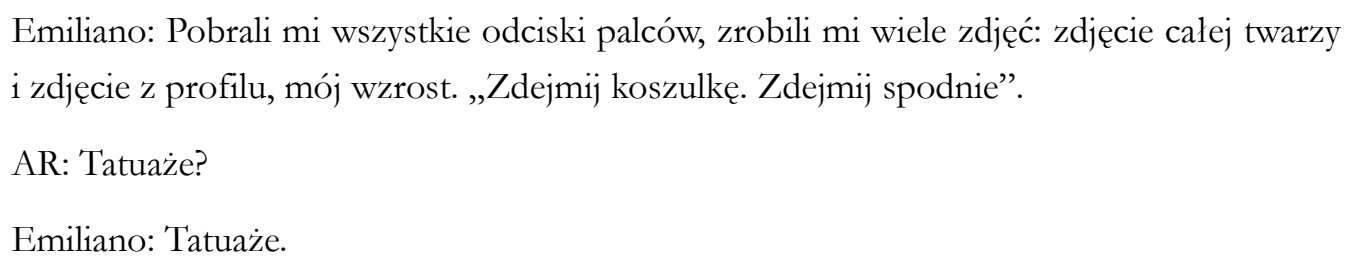

Javier: Zrobili nam [testy na] żółtaczkę, chyba, niektórzy już to mieli, już im to zrobili, więc oni mówili: „Nie, już to miałem, nie mogę dać się dwa razy kłuć”. Ale [doktor] mówi: „Nie, trzeba ci to zrobić, jeżeli nie chcesz, będziesz miał kolejny proces, trafisz do piekiełka”. [Piekiełko to] ciemny pokój, więc pozwalają sobie robić znowu zastrzyk.

Biometryczne procedury, które stosowane są także wobec więźniów, przyczyniają się do kryminalizacji deportowanych. Migranci, którzy przed deportacją nie byli w więzieniu, byli nimi zaskoczeni i zawstydzeni. Nie spodziewali się, że zostaną zamknięci w instytucji totalnej, ani że zostana poddani drobiazgowym kontrolom osobistym i badaniom medycznym.

Również transfer do Meksyku doświadczany jest jako kryminalizujący i przerażający. W drodze do Meksyku, w autobusie lub samolocie, deportowane osoby są unieruchomione przy pomocy kajdanek oraz połączonych łańcuchów. Jeden z nich oplata biodra, a drugi krępuje kostki. Czasem stosowane są metalowe rękawice unieruchamiające i raniące dłonie:

Javier: Około dwudziestu oficerów wsiadło do samolotu.

AR: Mają broń?

Javier: Tak, na przykład, jeśli chcesz iść do toalety, zabierają nas, ale skutych. Uwalniają tylko jedną rękę.

AR: Jak cię skuli? 
Javier: Kajdankami i łańcuchem. Ale w Arizonie jest inny rodzaj. Nazywaja go „skrzynka” [caja]. Coś jak skrzynka, umieszczają ją w połowie łańcucha. I z tym wsiedliśmy do autobusu [...] Źle jadą zdaje się, że celowo jadą po wybojach i chcesz to zatrzymać, ale nie możesz i ciagle cię rani.

AR: Z cego zrobiona jest skrzynka?

Javier: Z metalu. Dlatego, że jest niewygodna, ruszasz nia.

Coutin (2010, 361) pisze, że „kajdany [...] są szczególnie jaskrawym wskaźnikiem kryminalizowanej »nielegalności« i obcości". Podróżowanie w kajdankach wywołuje w deportowanych osobach poczucie niepewności i upokorzenia (zwłaszcza środki bezpieczeństwa dotyczące korzystania z toalety). Autobus i samolot to dla deportowanych przestrzenie fenomenologicznego zagrożenia (o przestrzeniach fenomenologicznego bezpieczeństwa, por. Willen 2007, 23).

Acacio: Oni rzeczywiście nas torturuja psychologicznie, kiedy nas strasza. Kiedy wyrzucili mnie [hiszp. me echaron] do Meksyku, kazali mi wsiasść do samolotu z łańcuchem tutaj [pokazuje na brzuch]. Nie możesz podnieść rąk, bo je krępuja. Męczysz się. Oto jak oni traktują większość ludzi.

Samolot i autobus, środki lokomocji służące deportacji „cudzoziemców”, to mobilne przestrzenie, w których władza suwerenna oprócz przemocy fizycznej sprawowana jest również z użyciem przemocy symbolicznej bazującej na kryminalizacji. Walters proponuje określenie „bryg”, nawiązując do okrętów żaglowych, na których pokutowali skazańcy. Definiuje on $(2015,98)$ bryg jako „sposób, w jaki więzienie lub areszt może zmaterializować się na statku, ale i na innych środkach lokomocji”. Samoloty i autobusy służące do transportu deportowanych to ilustracja brygu lub ruchomego obiektu, który stanowi zaprzeczenie swobody mobilności.

W trakcie aresztu imigracyjnego i przewiezienia do Meksyku migranci doświadczają dehumanizacji i animizacji. Częste są porównania do zwierząt hodowlanych - Acacio: „Skuwają nas, zakładają nam kajdanki na nogi, zakładaja nam tu łańcuch, jak zwierzętom”. Javier powiedział:

Większość czuła się jak bydło na farmie, stado krów. Porządek dnia: o 5:30 lub 6:30 idziesz na śniadanie. Jesteśmy tam chwilę i dają rozkaz przeliczenia. Jeden, dwa, trzy, cztery, pięć... 
To jak liczenie bydła. Przeliczaja nas trzykrotnie: w nocy i po południu. Dają nam legitymację ze zdjęciem, dostajesz numer łóżka.

Deportacja związana jest $\mathrm{z}$ transnarodowym kontinuum przemocy, ponieważ osoby deportowane sa wystawione na przemoc nie tylko w trakcie przekraczania granicy, na terytorium Stanów Zjednoczonych, podczas procesu deportacji, ale i po nim, już po powrocie na meksykańskie terytorium. Jak pisze Boehm (2011, 11), „przemoc i słabość (vulnerability) cyrkulują transnarodowo". Meksykanów deportuje się do meksykańskich miast przygranicznych. W Meksyku przemoc koncentruje się przede wszystkim tam, gdzie przebiegają trasy przemytu narkotyków, w tym na amerykańskiej granicy - Stany Zjednoczone deportuja ludzi do najniebezpieczniejszych części kraju (Kilpatrick 2014).

Etnografia deportacji wymaga poszukiwania przejawów podmiotowej sprawczości osób deportowanych (Lecadet 2013), w przeciwnym bowiem razie ryzykujemy wiktymizację aktorów „spektaklu na granicy”. Do przykładów oporu zaliczyć można na przykład opisane w literaturze: niszczenie dokumentów podróży i dowodów tożsamości (Darley 2009), strajki głodowe (McGregor 2011) czy samookaleczanie cudzoziemców (Fischer 2015), którzy $\mathrm{w}$ areszcie migracyjnym oczekuja na deportację. Moje badania nie dostarczają tak drastycznych przykładów oporu deportowanych. Narracje byłych deportowanych z San Ángel wskazuja natomiast na próby wytwarzania normalności w areszcie imigracyjnym, na przykład nawiązywania przyjaźni z innymi zatrzymanymi (por. McGregor 2012). Ponadto, czterech z dwudziestu siedmiu uczestników mojego badania wniosło apelację od wyroku „wydalenia” (por. Hasselberg 2016). Wszyscy oni przebywali poza aresztem imigracyjnym w trakcie procedur deportacyjnych, a troje miało silne wsparcie emocjonalne ze strony zamieszkujaccej w Stanach Zjednoczonych rodziny. Wniesienie apelacji to przykład podmiotowej sprawczości, którą proponuję nazwać kontrhegemoniczną (Mahmood 2001), to znaczy próby negocjowania swojej pozycji w legalnych ramach wyznaczonych przez deportujące państwo.

Podeportacyjny powrót do Stanów Zjednoczonych stanowi inny przykład oporu wobec reżimu deportacyjnego i amerykańskiego państwa (Schuster i Majidi 2015). Na deportowanych nakładane są często wieloletnie zakazy ponownego wjazdu, zatem ci, którzy wracają do Stanów Zjednoczonych, przedostają się tam przez zielona granicę. Sześciu moich rozmówców wróciło do USA w ten sposób; dwóch zostało zatrzymanych na amerykańskim terytorium, po czym skazano ich na karę więzienia federalnego za nieprzestrzeganie zakazu wjazdu i ponownie deportowano. Opór wobec amerykańskiego hegemona w formie penalizowanego powrotu stanowi przykład nieskutecznego wytwarzania rządomyślności - dyscyplinowania deportowanych za sprawą przemocy i manifestacji przytłaczającej władzy państwowej. 


\section{Wnioski}

Etnografia deportacji udziela głosu ludziom niechcianym przez „państwa przyjmujące”, rzucając tym samym światło na ciemną stronę migracji. W niniejszym artykule podjęłam próbę odpowiedzi na pytanie, jak deportacja jako „spektakl na granicy” (przy założeniu „wszechobecności granic”, por. Balibar 2002, 84) i jako wykluczenie budujące suwerenność państwa narodowego doświadczane jest przez deportowane osoby. W trakcie pobytu w Stanach Zjednoczonych moi rozmówcy starali się uniknąć kontaktu z amerykańską władzą i nie byli przez tę władzę uznani. Różnego rodzaju przemoc stosowana w trakcie zatrzymania i innych faz procesu deportacji rekonstruuje amerykańską suwerenność w miejscu cienistej strefy „nielegalności”. Przemoc jest odpowiedzią na kwestionowanie władzy państw narodowych $\mathrm{i}$ ich suwerennych granic.

Deportowani doświadczają nie tylko przemocy fizycznej, czasem używanej przez przedstawicieli amerykańskich władz (US BP, US ICE), ale i przemocy strukturalnej, która przyczynia się do ich deportowalności, oraz przemocy symbolicznej, która jest elementem procesu przed sądem imigracyjnym i która operuje przez kryminalizację deportowanych. Migranci padają ofiarami przemocy i są jej świadkami po obu stronach granicy państw narodowych. Doświadczaja przemocy w trakcie przekraczania granicy, w trakcie procesu deportacji i z powrotem w Meksyku, gdzie trafiaja do najniebezpieczniejszych miejsc (np. do przygranicznego stanu Tamaulipas, miejsca krwawej rywalizacji pomiędzy kartelami narkotykowymi). Poniższy graf obrazuje formy przemocy składające się na cykl przemocy doświadczany przez meksykańskich deportowanych:

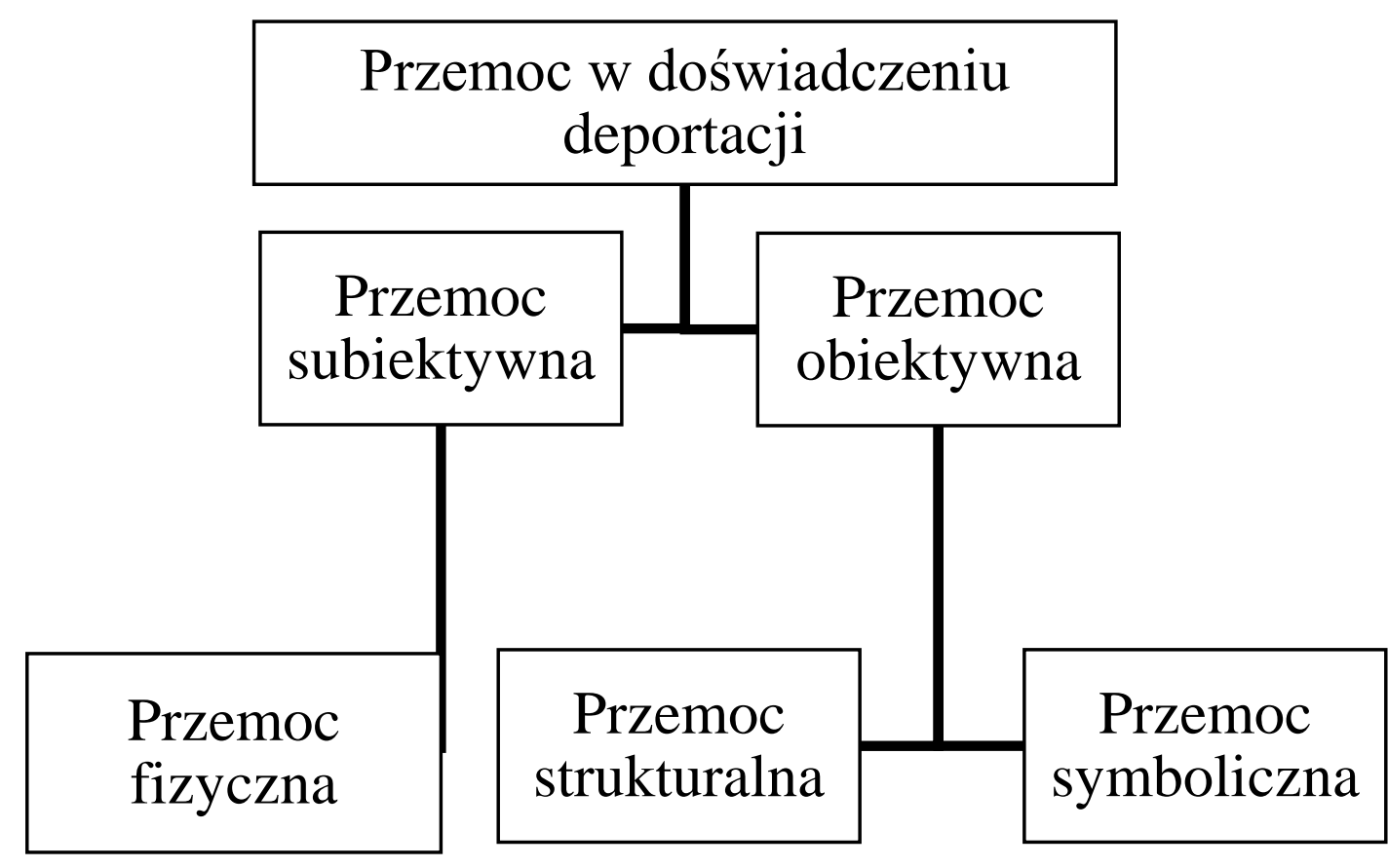

Rys. 1 Cykl przemocy doświadczany w trakcie deportacji z USA do Meksyku 
Aby lepiej zrozumieć cierpienie doznawane przez migrantów z Dolnej Mixteki, musimy porzucić optykę metodologicznego nacjonalizmu (Wimmer i Glick Schiller 2002) i uwzględnić ich położenie w strukturze społecznej w Meksyku i Stanach Zjednoczonych. W Stanach Zjednoczonych deportowalność migrantów jest wynikiem ubóstwa i marginalizacji ich miejsca pochodzenia oraz braku skutecznych programów socjalnych w neoliberalnym Meksyku. Podlegaja przemocy strukturalnej i przez migrację dążą do poprawy własnej sytuacji. Migracja bez wymaganych dokumentów naraża ich jednak na przemoc i upokorzenia. Na meksykańskoamerykańskim pograniczu przemoc strukturalna przekształca się w przemoc fizyczna. Jeśli mają szczęście i docierają na amerykańskie terytorium, ich amerykańscy pracodawcy zatrudniaja ich, by uniknąć niektórych wydatków, takich jak ubezpieczenie zdrowotne czy dodatkowe wynagrodzenie za nadgodziny i nie występują o wizy dla nich, co permanentnie spycha ich do cienistej strefy „nielegalności”. Strukturalna przemoc podbudowuje zatem rozróżnienie: „legalny” - „nielegalny migrant”. Migranci internalizuja ten podział i akceptuja swoje strukturalne podporządkowanie. Za sprawą przemocy symbolicznej osoby skazane na deportację rezygnuja z wniesienia apelacji przeciw nakazowi deportacji. Przyswajanie działań charakterystycznych dla identyfikacji „nielegalny imigrant” stanowi część „deportacyjnej gry” (Walters 2002) i stanowi przykład performatywnych zdolności przemocy symbolicznej.

W obliczu pozornej „utraty kontroli”, w państwach narodowych coraz częściej kryminalizuje się cudzoziemców oraz sięga się po deportację celem renegocjacji suwerenności. W ostatnich miesiącach w Polsce, Europie i w zachodnim świecie w ogóle jesteśmy świadkami umocnienia się wizerunku „cudzoziemca” stanowiącego zagrożenie dla bezpieczeństwa publicznego oraz wybuchu paniki moralnej związanej z niekontrolowanym przedostawaniem się potencjalnych przestępców przez państwowe granice. Deportacja to manifestacja ponownego zaprowadzania ładu w państwie narodowym, usunięcia tych, którzy zdołali uniknąc kontroli. Wydaje się, że współcześnie nie można sobie wyobrazić suwerenności bez deportacji.

W doświadczeniu meksykańskich deportowanych amerykańskie państwo lokowane jest za sprawa transnarodowego kontinuum przemocy. Za sprawa ich cierpienia odtwarzana jest współcześnie amerykańska suwerenność. Chociaż nie są amerykańskimi obywatelami, są niezbędni suwerenowi. Stają się bowiem aktorami „spektaklu na granicy”, czy to wtedy, gdy są zatrzymani w trakcie jej przekraczania, jak opisani w artykule Jennifer i Augustín, czy w na amerykańskim terytorium. Demonstracja przemocy wobec migrantów to symboliczny i performatywny spektakl przeznaczony dla dwóch grup odbiorców: obywateli i zbywateli. Deportowany odnawia wspólnotę narodowa, uosabia bowiem to, czego obywatele nie podzielaja - to biopolityczny obcy, inny pod względem rasowym („Hispanic”); jest też obcy pod względami prawnym („,cudzoziemiec”) i moralnym (,przestępca”), co zlepia się w figurę 
cudzoziemca-przestępcy (criminal alien). Dla obywateli „spektakl na granicy” to zatem symboliczne, ksenofobiczne i rasistowskie odtwarzanie granic wspólnoty narodowej. Stanowi on również jasny sygnał o konieczności przestrzegania prawa, którym objęci są wszyscy obywatele i zbywatele. W nieobywatelach kontinuum przemocy doświadczane przez deportowanych wytwarza rządomyślność. Dyscyplinuje ich: może prowadzić do większej ostrożności, by uniknąć deportacji, lub na odwrót - do autodeportacji ze strachu przed „wydaleniem”. Deportowanych i potencjalnych migrantów w Meksyku zniechęca do wyjazdu do Stanów Zjednoczonych. Rządomyślność ta zatem wytwarza amerykańską suwerenność poza granicami państwa. 


\section{Wykaz literatury}

Agamben, Giorgio. 2008. Homo sacer: suwerenna władza i nagie ṡycie. Tłum. Piotr Nowak. Warszawa: Prószyński i S-ka.

Arendt, Hannah. 1968. „On Humanity in Dark Times: Thoughts about Lessing.” W Arendt, Hannah, Men in Dark Times, New York: Harcourt, Brace \& World.

Balibar, Etienne. 2002. „What Is a Border?” W tegoż, Politics and the Other Scene: 75-86. London, New York: Verso.

Boehm, Deborah. 2011. „US-Mexico Mixed Migration in an Age of Deportation: An Inquiry into the Transnational Circulation of Violence.” Refugee Survey Quarterly 30 (1): 1-21.

Bourdieu, Pierre i Loïc Wacquant. 2001. Zaproszenie do socjologii refleksyjnej. Tłum. Anna Sawisz. Warszawa: Oficyna Naukowa.

Bourgois, Philippe. 2001. „The Power of Violence in War and Peace Post-Cold War Lessons from El Salvador." Etnography 2 (1): 5-34.

Breisblatt, Joshua. 2016. „Understanding Donald Trump’s Latest Deportation Threat.” Immigration Impact. http://immigrationimpact.com/2016/11/14/donald-trumpdeportation-plan/.

Castro Neira, Yerko. 2014. „Migraciones a Debate. Las Cuestiones Políticas En La Época de Los Regímenes de Terror." Desacatos 46: 32-51.

Chavez, Leo. 2012. Shadowed Lives: Undocumented Immigrants in American Society. Fort Worth: Harcourt Brace College Publishers, Wadsworth.

Cockcroft, James. 1986. Outlaws in the Promised Land: Mexican Immigrant Workers and America's Future. New York: Grove Press.

Correa, Jennifer. 2013. „»After 9/11 Everything Changed«: Re-Formations of State Violence in Everyday Life on the US-Mexico Border." Cultural Dynamics 25 (1): 99-119.

Coutin, Susan. 2000. „Denationalization, Inclusion, and Exclusion: Negotiating the Boundaries of Belonging." Idiana Journal of Global Legal Studies 7 (2): 585-593.

Coutin, Susan. 2010. „Exiled by Law: Deportation and the Inviability of Life.” W The Deportation Regime: Sovereignty, Space, and the Freedom of Movement, red. Nicholas De Genova i Nathalie Peutz, Durham: Duke University Press Books.

Darley, Mathilde. 2009. „L'enfermement des étrangers en Autriche et en République tchèque : du contrôle et de son contournemen." W Enfermés dehors : Enquêtes sur le confinement des étrangers, red. Carolina Kobelinsky i Chowra Makaremi, 63-83. Paris: Editions du Croquant.

De Genova, Nicholas. 2004. „The Legal Production of Mexican/Migrant »Illegality.«” Latino Studies 2 (2): 160-185.

De Genova, Nicholas. 2010. „The Deportation Regime: Sovereignty, Space, and the Freedom of Movement." W The Deportation Regime: Sovereignty, Space, and the Freedom of Movement, red. Nicholas De Genova i Nathalie Peutz, Durham: Duke University Press Books.

De León, Jason. 2015. The Land of Open Graves: Living and Dying on the Migrant Trail. Oakland: University of California Press. 
Dow, Mark. 2004. American Gulag: Inside U.S. Immigration Prisons. Berkeley: University of California Press.

Fischer, Nicolas. 2015. „The Management of Anxiety. An Ethnographical Outlook on SelfMutilations in a French Immigration Detention Centre." Journal of Ethnic and Migration Studies 41 (4): 599-616.

Foucault, Michel. 1991. „Governmentality.” W The Foucault Effect: Studies in Governmentality with Two Lectures by and an Interview with Michel Foucault, red. Graham Burchell, Colin Gordon i Peter Miller. Chicago: The University of Chicago Press.

Galtung, Johan. 1969. „Violence, Peace, and Peace Research.” Journal of Peace Research 6 (3): 167-191.

Gil Martínez de Escobar, Rocío. 2006. Fronteras de pertenencia: hacia la construcción del bienestar y el desarrollo comunitario transnacional de Santa María Tindú, Oaxaca. México: Universidad Autónoma Metroplitana.

Hasselberg, Ines. 2016. Enduring Uncertainty: Deportation, Punishment and Everyday Life. New York, London: berghanh.

Inda, Jonathan i Julie Dowling. 2013. „Introduction: Governing Migrant Illegality.” W Governing Immigration Through Crime, red. Jonathan Xavier Inda i Julie Dowling, Stanford: Stanford Social Sciences, an imprint of Stanford University Press.

Kandel, William i Douglas S. Massey. 2002. „The Culture of Mexican Migration: A Theoretical and Empirical Analysis." Social Forces 80 (3): 981-1004.

Kanstroom, Daniel. 2007. Deportation Nation: Outsiders in American History. Cambridge, Massachusetts; London: Harvard University Press.

Kearney, Michael. 2004. Changing Fields of Anthropology: From Local to Global. Lanham: Rowman \& Littlefield Publishers.

Kedar, Benjamin Z. 1996. „Expulsion as an Issue of World History.” Journal of World History 7 (2): 165-180.

Kilpatrick, Katy. 2014. „Into the Arms of the Cartels: Deported Mexicans Sent to City Ruled by Fear." Al Jazeera America, October 16.

http://america.aljazeera.com/articles/2014/10/16/deportedmexicanimmigrantspreyforcartels.html.

Lecadet, Clara. 2013. „From Migrant Destitution to Self-Organization into Transitory National Communities: The Revival of Citizenship in Post-Deportation Experience in Mali." W The Social, Political and Historical Contours of Deportation, red. Bridget Anderson, Matthew J. Gibney i Emanuela Paoletti, 143-158. New York: Springer.

Mahmood, Saba. 2001. „Feminist Theory, Embodiment, and the Docile Agent: Some Reflections on the Egyptian Islamic Revival." Cultural Anthropology 16 (2): 202-236.

Massey, Douglas, Jorge Durand i Nolan Malone. 2003. Beyond Smoke and Mirrors: Mexican Immigration in an Era of Economic Integration. New York: Russell Sage Foundation.

McGregor, JoAnn. 2011. „Contestations and Consequences of Deportability: Hunger Strikes and the Political Agency of Non-Citizens." Citizenship Studies 15 (5): 597-611.

McGregor, JoAnn. 2012. „Rethinking Detention and Deportability: Removal Centres as Spaces of Religious Revival." Political Geography 31 (4): 236-246. 
Ngai, Mae. 2004. Impossible Subjects: Illegal Aliens and the Making of Modern America. Princeton and Oxford: Princeton University Press.

Organization of American States. 1969. „American Convention on Human Rights.” http://www.oas.org/dil/treaties_B-

32_American_Convention_on_Human_Rights.htm.

Ortega, Bob. 2013. „Questions Linger over Teen Killed at Border.” Azcentral.com, October 9. http://www.azcentral.com/news/politics/articles/20131010questions-linger-overteen-killed-border.html.

Peutz, Nathalie. 2010. „»Criminal Alien« Deportees in Somaliland: An Ethnography of Removal." W The Deportation Regime: Sovereignty, Space, and the Freedom of Movement, red. Nicholas De Genova i Nathalie Peutz, Durham: Duke University Press Books.

Peutz, Nathalie i Nicholas De Genova. 2010. „Introduction.” W The Deportation Regime: Sovereignty, Space, and the Freedom of Movement, red. Nicholas De Genova i Nathalie Peutz, Durham: Duke University Press Books.

Pope, Paul i Terence Garrett. 2013. „America’s Homo Sacer: Examining U.S. Deportation Hearings and the Criminalization of Illegal Immigration." Administration \& Society, 167 186.

Preston, Julia. 2016. „Low-Priority Immigrants Still Swept Up in Net of Deportation.” The New York Times, June 24. http:/ / www.nytimes.com/2016/06/25/us/low-priorityimmigrants-still-swept-up-in-net-of-deportation.html.

Radziwinowiczówna, Agnieszka. 2014. „Subkultura gangsterska w meksykańskiej społeczności transnarodowej jako przykład transferu społecznego." Lud: Organ Polskiego Towarzystwa Ludoznawczego i Komitetu Nauk Etnologicznych Polskiej Akademii Nauk XCVIII: 229-252.

Radziwinowiczówna, Agnieszka. 2016. „Living/Leaving the Deportation Regime? Power and Violence in the Experience of Deportation.” Niepublikowana praca doktorska, Warszawa: Uniwersytet Warszawski.

Ramírez Valenzuela, Emilia. 2012. „Young Victims, Young Perpetrators? Anthropological Reflections on Agency and Subjectivity among Mexican Youth in the »War against Drugs«." Niepublikowana praca magisterska. Sussex: University of Sussex.

Riches, David. 1986. „Introduction.” W The Anthropology of Violence, red. David Riches, Oxford: Blackwell Publishing.

Sadowski-Smith, Claudia i Wei Li. 2016. „Return Migration and the Profiling of NonCitizens: Highly Skilled BRIC Migrants in the Mexico-US Borderlands and Arizona's SB 1070." Population, Space and Place 22 (5): 487-500.

Sáenz, Rogelio, Cecilia Menjívar i San Juanita Edilia García. 2013. „Arizona’s SB 1070: Setting Conditions for Violations of Human Rights Here and Beyond." W Governing Immigration Through Crime, red. Julie Dowling i Jonathan Xavier Inda, Stanford: Stanford Social Sciences, an imprint of Stanford University Press.

Sassen, Saskia. 2012. „Borders, Walls, and Crumbling Sovereignty.” Political Theory 40 (1): 116-122. 
Scheper-Hughes, Nancy i Philippe Bourgois. 2004. „Introduction: Making Sense of Violence." W Violence in war and peace: an anthology, red. Nancy Scheper-Hughes i Philippe Bourgois, Oxford: Blackwell.

Schuster, Liza, i Nassim Majidi. 2015. „Deportation Stigma and Re-Migration.” Journal of Ethnic and Migration Studies 41 (4): 635-652.

Schütz, Alfred. 1953. „Common-Sense and Scientific Interpretation of Human Action.” Philosophy and Phenomenological Research 14 (1): 1-38.

Schütz (jako Schuetz), Alfred. 1962. Collected Papers: The Problem of Social Reality. The Hague: Martinus Nijhoff.

Simanski, John. 2014. Immigration Enforcement Actions: 2013. Annual Report. Washington, DC: Department of Homeland Security. https://www.dhs.gov/sites/default/files/publications/ois enforcement ar 2013.pdf.

Soysüren, İbrahim, Kuvvet Lordoğlu i Ali Soysüren. 2016. „Deportation of Foreigners in Turkey: What Has Changed After the Law On Foreigners and International Protection and the Creation of the Directorate General of Migration Management? Evidence from Kocaeli.” W Turkish Migration 2016 Selected Papers, red. Jeffrey H. Cohen, Deniz Eroglu i Ibrahim Sirkeci. London: Transnational Press.

United Nations. 1948. „The Universal Declaration of Human Rights.” http://www.un.org/en/documents/udhr/.

U.S. Department of Homeland Security. 2016. 2015 Yearbook of Immigration Statistics. Washington, DC: U.S. Department of Homeland Security. https://www.dhs.gov/immigration-statistics/yearbook/2015.

U.S. Department of Homeland Security: Office of Inspector General. 2013. CBP Use of Force Training and Actions To Address Use of Force Incidents. Washington, DC: U.S. Department of Homeland Security. http://www.oig.dhs.gov/assets/Mgmt/2013/OIG_13114_Sep13.pdf.

Velasco, Laura i Marie Laure Coubés. 2013. Reporte sobre dimensión, caracterización y áreas de atención a mexicanos deportados desde Estados Unidos. Tijuana: El Colegio de la Frontera Norte.

Walters, William. 2002. „Deportation, Expulsion, and the International Police of Aliens.” Citizenship Studies 6 (3): 265-292.

Walters, William. 2015. „On the Road with Michel Foucault: Migration, Deportation and Viapolitics." W Foucault and the History of Our Present, red. Sophie Fuggle, Yari Lanci i Martina Tazzioli, New York: Palgrave Macmillan.

Willen, Sarah. 2007. „Toward a Critical Phenomenology of »Illegality«: State Power, Criminalization, and Abjectivity among Undocumented Migrant Workers in Tel Aviv, Israel." International Migration 45 (3): 8-38.

Wimmer, Andreas i Nina Glick Schiller. 2002. „Methodological Nationalism and beyond: Nation-State Building, Migration and the Social Sciences." Global Networks 2 (4): 301 334.

Žižek, Slavoj. 2010. Przemoc: Sžeść spojrzeńn zukosa. Tłum. Antoni Górny. Warszawa: Warszawskie Wydawnictwo Literackie Muza.

Znaniecki, Florian. 1922. Wstęp do socjologii. Poznań: Gebethner i Wolff. 
Agnieszka Radziwinowiczówna - antropolożka społeczną i iberystka, pracuje jako adiunktka w Ośrodku Badań nad Migracjami Uniwersytetu Warszawskiego. Jej praca doktorska obroniona z wyróżnieniem na Uniwersytecie Warszawskim dotyczyła doświadczenia deportacji ze Stanów Zjednoczonych Ameryki do Meksyku. Agnieszka jest współautorką książki Migrants as Agents of Change: Social Remittances in an Enlarged European Union (Grabowska, Garapich, Jaźwińska, Radziwinowiczówna 2017). Obecnie prowadzi badania dotyczące związanych z międzynarodowymi migracjami przemian wzorców opieki nad seniorami.

\section{DANE ADRESOWE:}

Ośrodek Badań nad Migracjami

Uniwersytet Warszawski

ul. Banacha 2b

02-097 Warszawa

EMAIL: a.radziwinowicz@uw.edu.pl

CYTOWANIE: Radziwinowiczówna, Agnieszka. 2016. Doświadczenie deportacji: Przemoc orężem suwerenności. Praktyka Teoretyczna 3 (21): 54-76.

DOI: $10.14746 /$ prt.2016.3.2

AUTHOR: Agnieszka Radziwinowiczówna

TITLE: The Experience of Deportation: Violence as a Weapon of Sovereignty

ABSTRACT: Researchers (Walters 2002; De Genova 2010) argue that deportations and their sheer possibility - the deportability of migrants - produce state sovereignty against the uncontrolled border-crossings, which are perceived by states as a disturbing symptom of 'losing control' (Sassen 1996). This article assumes a micro-perspective and, drawing upon the phenomenologically-informed concept of 'state as lived experience' (Correa 2013), it explains how state sovereignty is localized in the experience of a deportee. The narratives of 27 former deportees, expelled from the United States between 2006 and 2012 and interviewed back in their Mexican hometown, are the basis for the analysis. The author argues that a continuum of violence experienced by the migrants throughout the process of deportation reconstructs US sovereignty in lieu of an extralegal zone, the corollary of migrants' unauthorized border crossings.

KEYWORDS: violence, deportation, sovereignty, migration, Mexico, United States of America 